\title{
REGIONAL CLIMATE CHANGE IMPACTS ON WILD ANIMALS' LIVING TERRITORY IN CENTRAL EUROPE
}

\author{
BARTHOLY, J. ${ }^{1}{ }^{*}$ - PONGRÁCZ, R. ${ }^{1}$ - NAGY, J. ${ }^{1}$ - PIECZKA, I. ${ }^{1}$ - HufNAGEL, L. ${ }^{2,3}$ \\ ${ }^{1}$ Eötvös Loránd University, Department of Meteorology \\ 1117 Budapest, Pázmány Péter sétány 1/A., Hungary \\ (phone: +36-1-372-2945; fax: +36-1-372-2904) \\ ${ }^{2}$ Corvinus University of Budapest, Adaptation to Climate Change Research Group \\ 1118 Budapest, Villányi út 29-43., Hungary \\ ${ }^{3}$ Corvinus University of Budapest, Department of Mathematics and Informatic \\ 1118 Budapest, Villányi út 29-43., Hungary \\ (phone+36-1-482-6261; fax: +36-1-466-9273) \\ *Corresponding author \\ e-mail: bari@ludens.elte.hu
}

(Received $30^{\text {th }}$ November 2011; accepted $10^{\text {th }}$ January 2012)

\begin{abstract}
In this paper the projected future impact of climate change has been analyzed for the quality of living conditions of the European terrestrial vertebrates (amphibians, reptiles, birds, mammals) in the Carpathian Basin. According to the climate scenarios, warmer and drier climatic conditions are likely to occur in the Carpathian Basin by end of this century. Simultaneous analysis of climate parameters, climate simulations and animal range datasets enables us to evaluate the vulnerability of different European species to regional warming and climate change. The spatial climate analogy technique is used to analyze the estimated rapid change of the wild animals' habitats and their northward migration. For the reference climate data of Debrecen is considered, and three spatial analogue regions are compared. The results suggest that generally a significant decline in habitats is very likely for most of the analyzed animal groups by the end of the $21^{\text {st }}$ century. The largest rate of decline is estimated for birds. However, living conditions for reptiles may improve in the future due to the warmer and drier climatic conditions, which are favourable for these species.
\end{abstract}

Keywords: spatial analogy, climate change, vertebrates species, ecology, area dynamics

\section{Introduction}

Global climate change does not affect only humans and the urban environment, but also, the living conditions of wild animals. The analysis of phenological, geographical and genetic impacts of climate change to wildlife is an increasingly popular research topic (e.g., Thomas et al., 2004; Rosenzweig et al., 2008; Moritz et al., 2008; Diós et al., 2009; Drégelyi-Kiss and Hufnagel, 2009; Eppich et al., 2009; Sipkay et al., 2008, 2009; Chen et al., 2011), however, the projections of future conditions are rarely investigated due to the lack of methodology. The results suggest that the relationship between global warming and the response of the wildlife is clearly strong.

Climate is one of the abiotic factors, which controls primarily the range areas of the wildlife. According to the Niche theory (Jackson and Overpeck, 2000) in a particular region, multivariate changes in climate imply shifts in species' range areas because each species reacts individually (Williams et al., 2007).

If the climate significantly changes in a particular region, it may disturb the ecosystem, and increase the risk of extinction. Based on previous studies (e.g., Williams 
et al., 2007) accomplished in case of the A2 scenario (Nakicenovic and Swart, 2000), $12-39 \%$ of the Earth's terrestrial surface is very likely to experience significantly different climate conditions from the current climate in the future.

Because of the warming, some species colonize new regions, others move towards presently yet colder climatic zones. However, in case of some other wildlife species, it may be especially difficult to adapt to the accelerating warming. For instance, Beever et al. (2011) concluded that the wild mountain-dwelling pikas of North America migrated upward at an average of $13 \mathrm{~m}$ per decade throughout the $20^{\text {th }}$ century, and this rate increased up to $145 \mathrm{~m}$ per decade in the last 12 years. According to Chen et al. (2011) the range of species of North America and Europe shifted poleward $17 \mathrm{~km}$ per decade, and to higher elevation at a rate of $11 \mathrm{~m}$ per decade in the recent decades. As species move from their previous ranges, they meet other species, sometimes unprecedently, which affects the whole ecosystem of the region.

Mountain ecosystems have very diverse wildlife, thus, they are major areas of biodiversity (Balogh et al., 2008). Increasing temperature is estimated to cause significant loss of appropriate environment of all regionally endemic animals. These possible losses may increase if the warming compared to present climate is larger than $2^{\circ} \mathrm{C}$. According to estimation of Williams et al. (2003), even with an optimistic temperature increase of $1{ }^{\circ} \mathrm{C}$, one endemic species will entirely lose its habitat and almost all other endemic species will suffer severe decreases in their range areas of the Australian Wet Tropics bioregion. Moreover, in the case of a large warming (exceeding $7^{\circ} \mathrm{C}$ ), all of the endemic species will lose their previous habitats.

The species that are affected the most negatively by climate change are the habitat specialists, and the species being less mobile. Species that live in fragmented landscapes may also struggle with the negative impacts of climate change because they are not able to colonize the area (Chen et al., 2011).

Each species has its own climatic and environmental needs and tolerances. If these conditions change (e.g., by climate change) they may shift their ranges, or regulate their morphology, shifting the timing of life-cycle events or in the worst case, they may suffer extinction (Rosenzweig et al., 2007). Because of the large number of endangered species, several analyses focus on extinctions due to climate change recently (e.g., Burrowes et al., 2004; Sekercioglu et al., 2004; Pounds et al., 2006; McLaughlin et al., 2002). Specifically, 75 endemic frog species in the American tropics are extinct because of a pathogenic fungus (Batrachochytrium dendrobatidis) infection due to recent warming (Pounds et al., 2006). Furthermore, a native butterfly, Euphydryas editha bayensis in the San Francisco Bay area in California is another victim of global warming because its total habitat loss and thus, extinction in the region were due to the increasing variability in precipitation (McLaughlin et al., 2002). Based on the study of Sekercioglu et al. (2004) $21 \%$ of 9916 historic bird species of the world are threatened by extinction, and $6.5 \%$ of the analyzed IUCN Red List avian species are functionally extinct. According to the estimations, 6-14\% of all historic bird species will be extinct, $7-25 \%$ will be functionally extinct, and $13-52 \%$ will be functionally deficient by the end of the $21^{\text {st }}$ century (Sekercioglu et al., 2004).

Besides vertebrates, even insects show a very sensitive reaction to the change of abiotic factors of the environment (Ladányi and Hufnagel, 2006; Ferenczy et al., 2010). Therefore, they can be considered as a good indicator species of climate change (Gergócs and Hufnagel, 2009; Gergócs et al., 2010). For instance, a recent paper by Kocsis and Hufnagel (2011) of the impacts of climate change on the fourth largest order 
of insects in Europe discussed remarkable changes in abundance, distribution range and phenology of Lepidoptera.

The above mentioned studies all highlight the importance of this global issue and the need of further research to understand the mechanisms of climate stress to ecosystems. Such detailed analysis may help to minimize these negative impacts of global warming to the wildife and ecosystems before it would be irreversible.

The research presented in this paper aims to evaluate the regional impacts of climate change on the habitats of wild European vertebrates (amphibians, reptiles, birds, mammals). The method of spatial climate analogy (Horváth, 2008b) has been used to analyze the possible future climatic conditions in Eastern Hungary by the late $21^{\text {st }}$ century. Global warming implies increasing temperature, dryer summers and wetter winters in the region (Bartholy et al., 2008), which is similar to the current Mediterranean climate, therefore, the climate analogy sites are located south, southeast to Hungary. Comprehensive habitat and climate analysis enables us to evaluate the sensitivity of the European vertebrate species to regional warming and climate change.

\section{Database}

Three datasets were used for the range of species:

- The Atlas of European Mammals (available from Societas Europaea Mammalogica, http://www.european-mammals.org/php/mapmaker.php). This database was compiled in 1999 (Mitchell-Jones et al., 1999) and has been widely used as reference dataset. It separately contains data for the pre-1970 and post-1970 presence of mammal species in Europe.

- The Atlas of European Breeding Birds (available from the European Bird Census Council, EBCC, http://www.sovon.nl/ebcc/eoa), which contains information on bird species (Hagemeijer and Blair, 1997). In case of both mammals and birds, the range of species determined from the datasets may not be precise for the Eastern European regions, i.e., it is possible that several species are only missing due to not detecting them.

- The Atlas of Amphibians and Reptiles (available from the European Societas Europaea Herpetologica, http://www.seh-herpetology.org), which contains spatial distribution information about these species. This database was published in 1997 (Gasc et al., 1997) and was collected on the basis of observations in the 1980s and 1990s.

From the above datasets, altogether 234 mammal species, 58 bird species, 123 reptile species, and 61 amphibian species were analyzed in the present study.

The climate information includes daily temperature and precipitation, which is available from the E-OBS datasets (Haylock et al., 2008). The climatic conditions of Debrecen in 1961-1990 are illustrated in Fig. 1. The red curve of the diagram shows the annual distribution of monthly mean temperature values, the blue histograms indicate the average monthly precipitation amounts. 


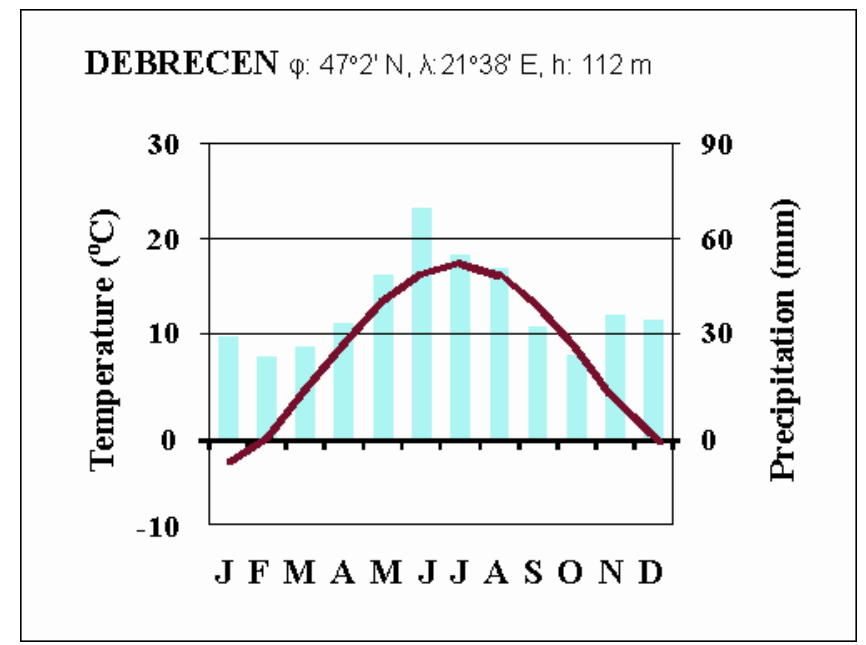

Figure 1. Climate diagram representing the climate conditions in Debrecen (1961-1990)

\section{The methodology of spatial analogy}

The spatial analogy technique is based on the temperature and precipitation time series. Horváth $(2007,2008 \mathrm{a}, 2008 \mathrm{~b})$ applied the analogy of the search process for the area of Debrecen (Hungary, $47^{\circ} 2$ ' N, $21^{\circ} 38^{\prime}$ E) using the pessimistic A1FI, and the optimistic B2 scenario (Nakicenovic and Swart, 2000). With the so-called CLIMEX method (Eq. 1) (Sutherst and Maywald, 1998; Young et al., 1999), it is possible to determine the spatial climate analogy regions, for which the following formulae can be used:

$$
\begin{aligned}
& T_{d j}=\frac{1}{12} \cdot \sum_{i=1}^{12} \mid \text { TEMP }_{j i}-T_{i} \mid \\
& P_{d j}=\frac{1}{12} \cdot \sum_{i=1}^{12} \frac{\mid \text { PREC }_{j i}-P_{i} \mid}{1+a \cdot\left(\text { PREC }_{j i}+P_{i}\right)} \\
& I_{T j}=e^{-k_{T} \cdot T_{d j}} \\
& I_{P j}=e^{-k_{P} \cdot P_{d j}} \\
& C M I_{j}=\sqrt{I_{T j} \cdot I_{P j}}
\end{aligned}
$$

where,

$j:$ number of the gridpoint $(j=1, \ldots, 31143)$

$i$ : number of the month $(i=1, \ldots, 12)$

$T E M P_{j i}$ : the temperature of the grid $j$ in the month $i$

$T_{i}$ : the temperature of the scenario in month $i$

$P R E C_{j i}$ : the precipitation of the grid $j$ in the month $i$

$P_{i}$ : the precipitation of the scenario in month $i$

$T_{d j}$ : the absolute differences of temperature

$P_{d j}$ : the differences of precipitation 
$a$ : we can count only the differences of precipitation, because the differences for small precipitation is more important than for the high ones. For the calculation we used $a=0,05$

$I_{T j}$ : the similarity of the grid $j$ by the temperature to the scenario (value: $0-1$, if the temperature is the same, than $\mathrm{I}_{\mathrm{Tj}}=1$ )

$I_{P j}$ : the similarity of the grid $j$ by the precipitation to the scenario (value: $0-1$, if the precipitation is the same, than $I_{P j}=1$ )

$k_{T}$ : can be set by the user, if $k_{T}=0.1$ than for $1^{\circ} \mathrm{C}$ differences the similarity is $I_{T j}=0.9$, to define the analogue regions, we used the value $k_{P}$ : can be set by the user, we choose the $k_{P}=0.1$

$C M I_{j}$ : „Composite Match Index”, the similarity between the gridpoint and the scenario, for the perfect similarity the value is $C M I=1$

The center of the three regions derived from the method of spatial climate analogies (Fig. 2) indicate the possible future climatic conditions for the region of Eastern Hungary (represented by Debrecen as the largest city in the area with reliable observed meteorological time series) in the $21^{\text {st }}$ century. Climate conditions similar to the present conditions of Timisoara and Russe are estimated by the middle of the $21^{\text {st }}$ century, and conditions similar to the present conditions of Thessaloniki by the end of the century. The details of the entire selection process of the spatial climate analogy regions represented by the above mentioned cities are described by Horváth $(2007,2008 b)$.

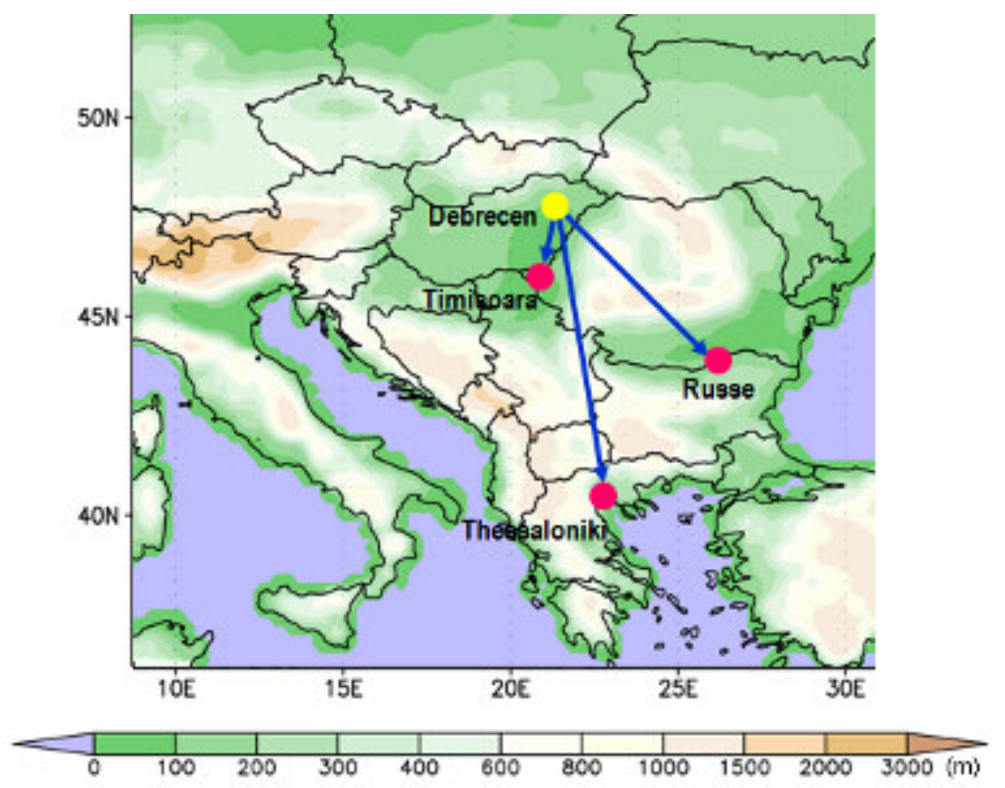

Figure 2. Location of the climate analogue sites

The climate diagrams of Fig. 3 show that warmer climatic conditions and significantly decreasing summer precipitation are projected in the region by the end of the $21^{\text {st }}$ century. Current climatic conditions of the spatial analogue sites are presented in the left column (in similar forms to Fig. 1) while the difference between the analogue sites and Debrecen (implying the projected climatic changes) can be seen in the right column. The larger the geographical distance between the spatial analogue site and Debrecen, the warmer the climate and the drier the summer. First, summer climate of Timisoara is only slightly warmer and drier than that of Debrecen: the anomalies of the 
monthly mean temperature do not exceed $2^{\circ} \mathrm{C}$, and the monthly precipitation anomalies do not exceed $10 \mathrm{~mm}$. This slight difference can naturally be explained by geographical proximity. In the temperature conditions of Russe the differences in summer can exceed $4^{\circ} \mathrm{C}$ and the difference of the summer monthly precipitation exceeds $20 \mathrm{~mm}$. The greatest climatic anomalies compared to Debrecen occur in Thessaloniki, located on the southernmost, which is projected to characterize Debrecen by the late $21^{\text {st }}$ century (Bartholy et al., 2008). The summer temperature differences between Thessaloniki and Debrecen are $6-7^{\circ} \mathrm{C}$, and monthly precipitation decrease is about $40-50 \mathrm{~mm}$.

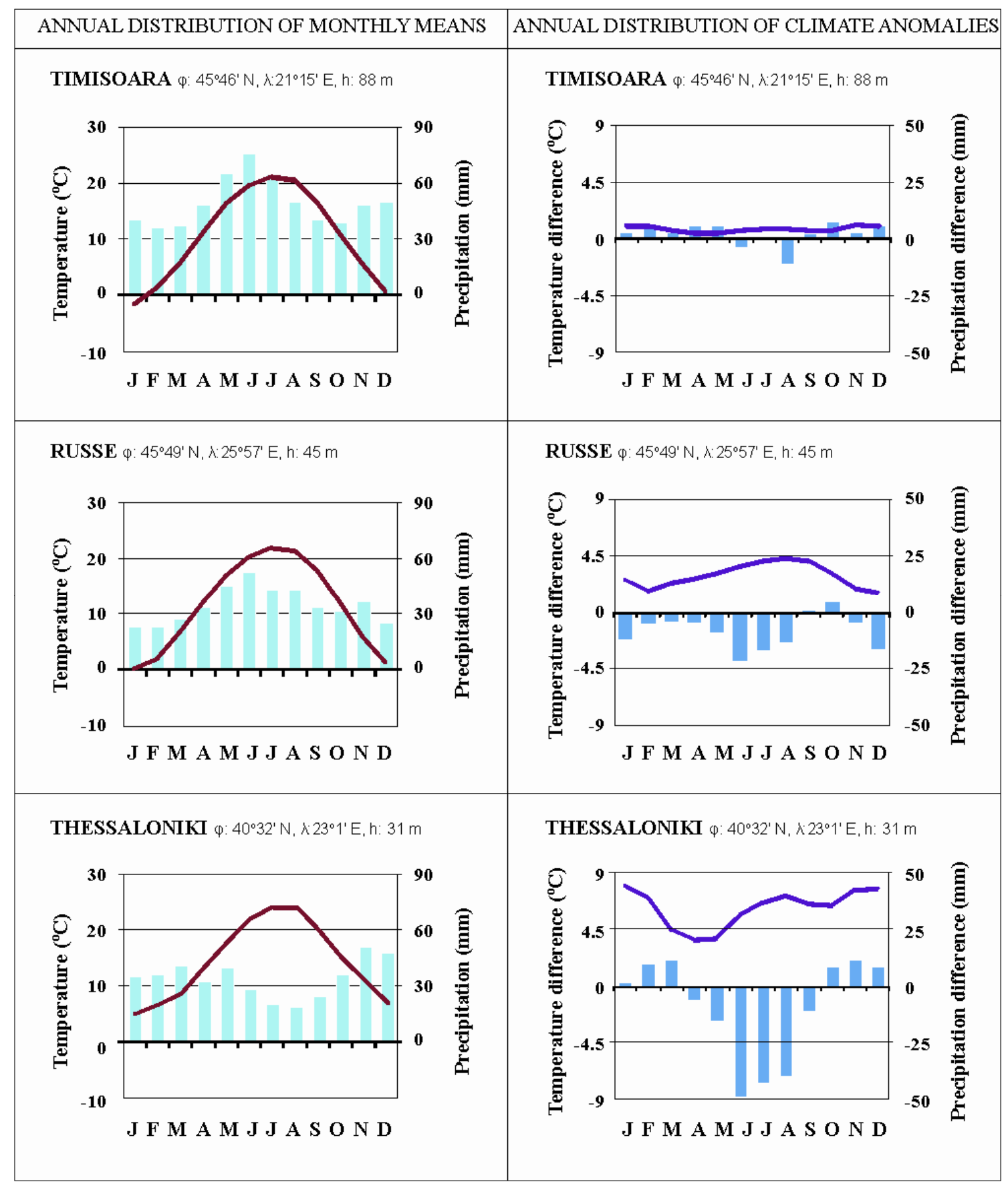

Figure 3. The climatic conditions of the climate analogue sites

(Timisoara, Russe, Thessaloniki). 


\section{Classification system based on living conditions of species}

For the analysis of the change in the range of different vertebrate species, the applied classification system contains four different basic codes: (i) 'Absent', i.e., there are no suitable habitat for the particular animal in the region; (ii) 'Marginal', i.e., the range area is located on the border of the spread area of the particular animal; (iii) 'Sporadic', i.e., the location of the habitats are not a continuous distribution area of the particular animal; (iv) 'Area central' considered to be the best conditions for the particular animal because the range area is centrally located.

The quality of living conditions for every terrestrial vertebrate has been determined in the Debrecen region and in the three analogue regions. The resulting sixteen variations of code-pairs can be divided into three classes in terms of changing in their habitat quality. The first six code-pairs (i.e., Absent - Area central, Absent - Sporadic, Marginal - Area central, Absent - Marginal, Sporadic - Area central, Marginal Sporadic) imply positive changes or improving conditions. Three code-pairs (i.e., Area central - Area central, Sporadic - Sporadic, Marginal - Marginal) imply unchanged situation. The last six code-pairs (i.e., Area centrale - Sporadic, Sporadic - Marginal, Area centrale - Marginal, Marginal - Absent, Sporadic - Absent, Area centrale Absent) imply negative change or decreasing habitat. Since the 'Absent' - 'Absent' code pair is not relevant in the analysis, it was omitted from the classification system. For the animals, the most negative habitat change is to shift from the 'Area central' to the 'Absent' condition, which means the extinction of the particular species. On the other hand, the most positive change is the change from the 'Absent' status to 'Area central'. This classification unables us to identify the endangered species, the new immigrant species, and a detailed analysis of different species' habitats.

\section{Results}

We analyzed the change of habitat quality in case of all four classes of vertebrate animals separately in Debrecen and in the three spatial analogue regions. The results of changing habitats (i.e., the code-pairs) are summarized in Fig. 4 as a distribution using pie charts for all the four classes of vertebrates. Blue colors indicate decreasing habitat of the animals, while yellow and red colors indicate improved conditions for the species. Grey colors imply unchanged conditions. In case of amphibians no major changes can be projected in living conditions by the mid-century, but a significant decline is expected by the end of the century. The living conditions of reptiles clearly show an improving trend of their conditions, which is due to the fact that the warmer and drier climatic conditions are favorable for these species. The largest portion of decrease is projected for the birds since the conditions become less favorable. The portion of bird species with decreasing habitat conditions can exceed $60 \%$ by the end of the $21^{\text {st }}$ century.

In case of mammals, different species react very differently to the changing climatic conditions, thus, some species may benefit from the regional climate change, others will lose their habitats. By the end of the century the living conditions of $48 \%$ and $31 \%$ of mammal species are projected to decrease and increase, respectively. 


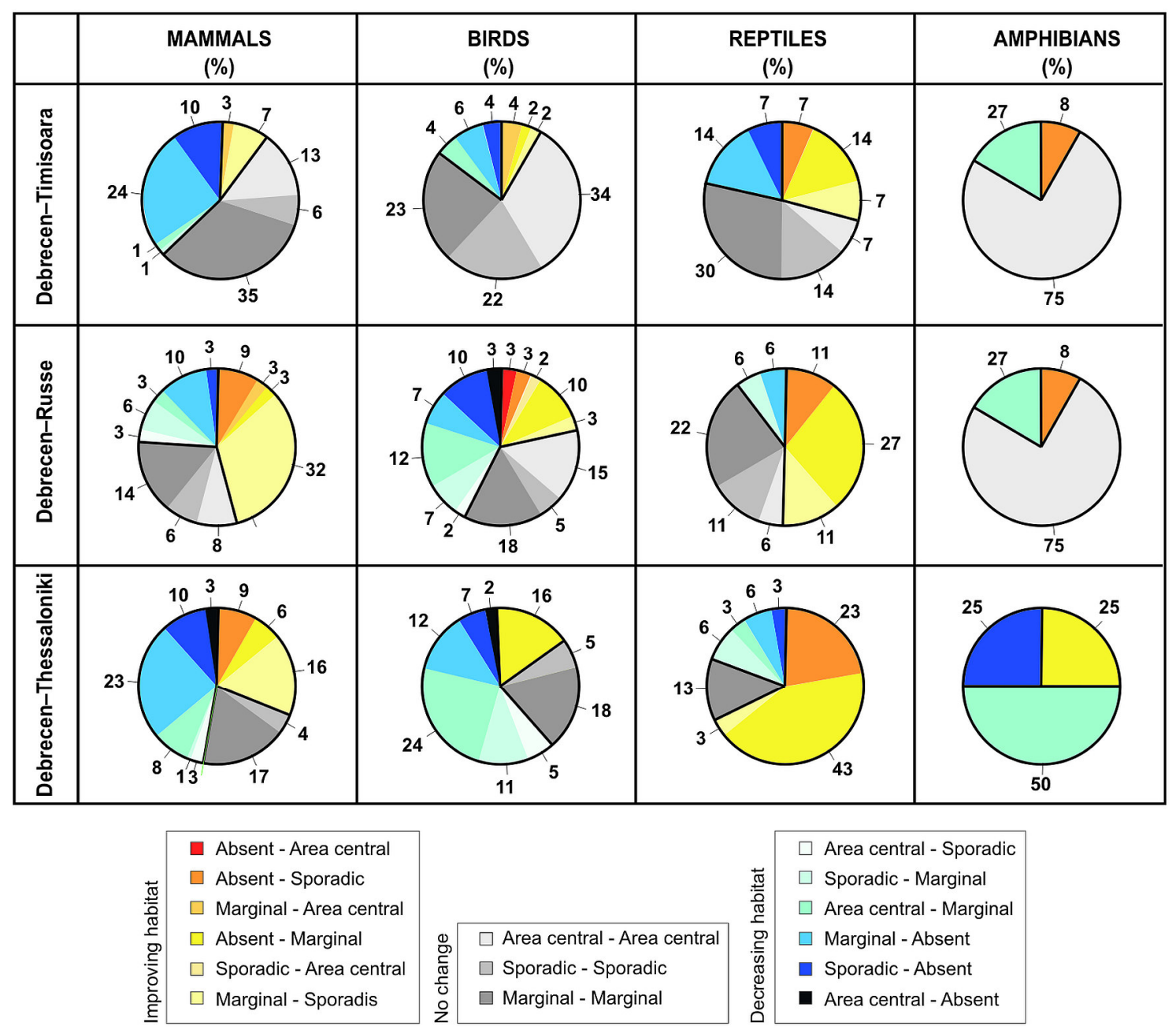

Figure 4. The distibution of habitat changes of the four groups of animals on the climatic analogue regions

Results of regional climate change studies suggest that the climate of the Carpathian Basin is expected to be drier and warmer by the end of the $21^{\text {st }}$ century (Bartholy et al., 2008), therefore it is assumed that the migration of animals will shift northward.

The climate change affects the amphibians especially negatively because they are water-bound animals and hence, the estimated drying leads to decrease of the optimal habitats. Among amphibians the following species will probably suffer the strongest habitat decrease by the end of the century: Bombina bombina - European fire-bellied toad, Palobates fuscus - common spadefoot toad, Rana esculenta complex - edible frog, Rana arvalis - moor frog.

The reptiles are well-known of their preference of warm areas (due to the lack of an appropriate heat-balancing cardiovascular system), therefore, the projected temperature increase will be generally beneficial for them. However, the living conditions of the following species may be threatened by the effects of climate change: Zootoca vivipara - common lizard, Lacerta agilis - sand lizard, Ablepharus kitaibelii - European copper skink. 
Based on our analysis the following bird species are likely to be the most negatively affected by the climate change: Acrocephalus paludicola - aquatic warbler, Circus pygargus - Montagu's harrier, Limosa limosa - black-tailed godwit, Numenius arquata - Eurasian curlew, Asio flammeus - short-eared owl, Otis tarda - great bustard.

Fig. 5 summarizes the spread of endangered mammal species in Europe and in the Carpathian Basin. Among these mammals the following species are likely to lose partially their habitats in the Carpathian Basin in the future: Castor fiber - Eurasian beaver, Myotis dasycneme - pond bat, Barbastella barbastellus - western barbastelle, Lynx lynx - Eurasian lynx, Mustela erminea - stoat, Oryctolagus cuniculus - European rabbit.

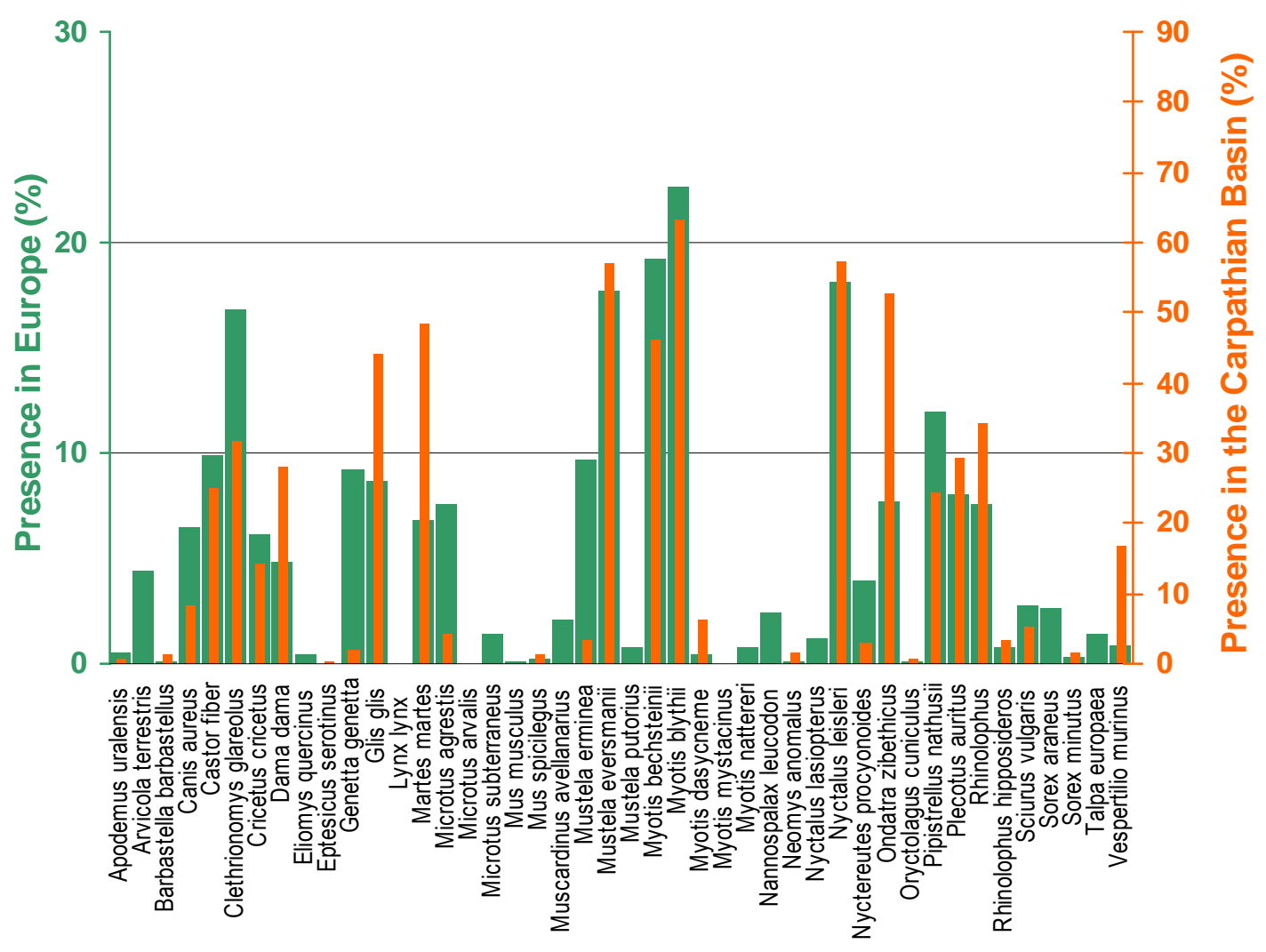

Figure 5. Current presence of possibly endangered European mammal species in the whole area of the European continent and the Carpathian Basin.

(In any climate analogue site the given species' habitat is classified as 'Absent')

Fig. 6 shows the distribution map of the six mammal species, which are categorized - based on the Atlas of European Mammals database - 'absent' in all three analogue regions, while in the Debrecen region they are categorized as 'marginal' or 'sporadic' living conditions. Our results suggest that it is likely that the future climate of Hungary will not be suitable for these six mammal species. 

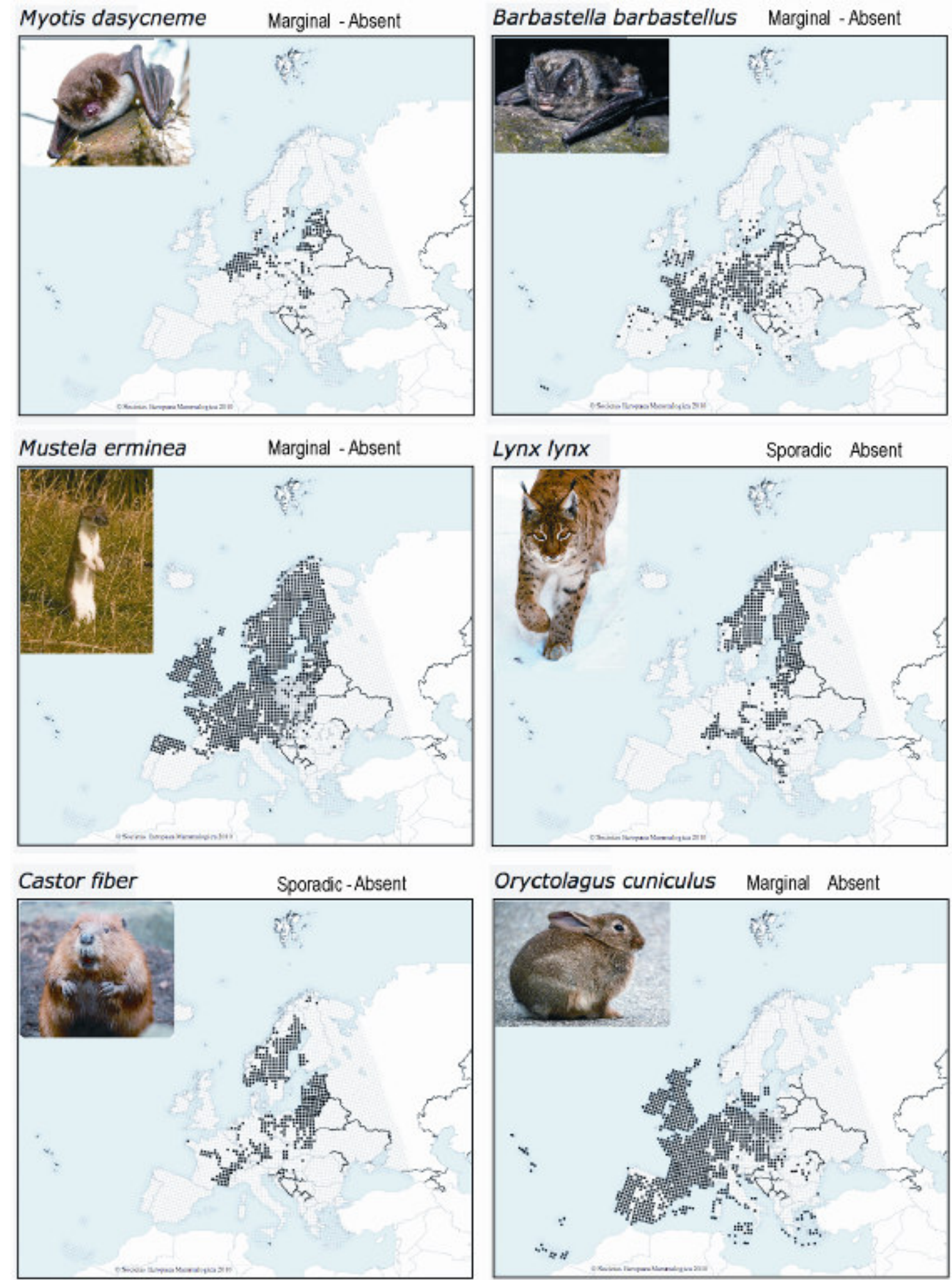

\section{Legend}

- Species Present Post 1970 - Species Present Pre 1970

Figure 6. The species of which the habitats of all the climate analogue sites are classified as 'Absent' are shown in more details on the range maps determined ont he basis of datasets from Mitchell-Jones et al. (1999) 


\section{Conclusion and discussion}

The purpose of this reasearch was to analyze the possible regional impacts of the global warming to the living territory and conditions of the four wild European terrestrial vertebrate groups (amphibians, reptiles, birds, mammals). Climate analogy technique enables us to estimate the migration tendecies of these animals during the $21^{\text {st }}$ century. However, the validity of the results analyzed in this paper is limited since the living territory of the species and its changes are not only dependent on temperature and precipitation.

In case of the four examined vertebrate groups the portion of species with decreasing habitat conditions is estimated to be between $18 \%$ and $61 \%$, while that with increasing habitat conditions between $16 \%$ and $69 \%$ by the end of the $21^{\text {st }}$ century. This result is very similar to that of Petrányi et al. (2007). According to their study $33 \%$ of the Lepidoptera species is predicted to have decreasing, while $26 \%$ of them to have increasing habitat conditions by the end of the $21^{\text {st }}$ century.

As we proceed southward from Timisoara to Thessaloniki the portion of species with unchanged habitat conditions decreases from $54 \%$ to $21 \%$ in case of mammals, $78 \%$ to $23 \%$ in case of birds, $51 \%$ to $13 \%$ in case of reptiles, and $75 \%$ to $25 \%$ in case of amphibians. Petrányi et al. (2007) predicted the Lepidoptera species to be between $67 \%$ to $41 \%$ (79\% to $51 \%$ in case of Macrolepidoptera, and $61 \%$ to $34 \%$ in case of Microlepidoptera), under the same conditions, with the same analogue places.

We can predict a $17 \%$ decrease in mammal biodiversity, a $45 \%$ decrease in bird biodiversity, while a $51 \%$ increase in the biodiversity of reptiles, by the end of $21^{\text {st }}$ century (based on Thessaloniki as an analogue place). In the case of amphibians we estimate a $50 \%$ species replacement without the change of biodiversity. Based on the data of Petrányi et al. (2007) Lepidoptera biodiversity is estimated to decrease by $7 \%$ (a deacrease of $18 \%$ in case of Microlepidoptera and a $9 \%$ increase in case of Macrolepidoptera).

According to the climate change estimations for the Carpathian Basin, warmer and drier climate conditions are projected. Our results based on the climate analogue technique suggest a remarkable change in the habitats of wild animals and their northward migration in order to find their optimal conditions. More specifically, the following conclusions can be drawn.

1. Among the four animal groups analyzed in this paper, the birds are likely to be affected the most negatively by the regional climate change.

2. Since reptiles prefer warm and dry climatic conditions, therefore, the estimated climate change in the region improves their living conditions.

3. In the case of mammals, species respond differently to the changing climatic conditions, thus, some species may benefit from the regional climate change, while others will lose their habitats.

4. Because of the barrier effect of the Carpathian Basin, some species could suffer extinction due to the lack of escape routes. This effect was not taken into consideration in this study. 
Acknowledgements. Research leading to this paper has been supported by the following sources: the Hungarian Academy of Sciences under the program 2006/TKI/246 titled Adaptation to climate change, the Hungarian National Science Research Foundation under grants K-78125, K-69164, and K-67626, the Hungarian Ministry of Environment and Water under the National Climate Strategy Development project, the Bolyai János Research Scholarship of MTA Doctoral Council, the European Union and the European Social Fund (TÁMOP-4.2.1/B-09/1/KMR-2010-0003 and TÁMOP-4.2.1/B-09/1/KMR-2010-0005).

\section{REFERENCES}

[1] Bartholy, J., Pongracz, R., Gelybó, Gy., Szabó, P. (2008): Analysis of expected climate change in the Carpathian basin using the PRUDENCE results. - Idojjárás 112: 249-264.

[2] Balogh, P., Gergócs, V., Hufnagel, L., Farkas, E., Farkas, P., Kocsis, M. (2008): Oribatid assemblies of tropical high mountains on some points of the "Gondwana-Bridge" - a case study. - Applied Ecology and Environmental Research 6(3): 127-159.

[3] Beever, E.A., Ray, C., Wilkening, J.L., Brussard, P.F., Mote, P.W. (2011): Contemporary climate change alters the pace and drivers of extinction. - Global Change Biology 17: 2054-2070.

[4] Burrowes, P.A., Joglar, R.L., Green D.E. (2004): Potential causes for amphibian declines in Puerto Rico. - Herpetologica 60: 141-154.

[5] Chen, I.C., Hill, J.K., Ohlermüller, R., Roy, D.B., Thomas, C.D. (2011): Rapid range shifts of species associated with high levels of climate warming. - Science 333: 10241026.

[6] Diós, N., Szenteleki, K., Ferenczy, A., Petrányi, G., Hufnagel, L. (2009): A Climate profile indicator based comparative analysis of climate change scenarios with regard to maize (Zea mays L.) cultures. - Applied Ecology and Environmental Research 7(3): 199214.

[7] Drégelyi-Kiss, A., Hufnagel, L. (2009): Simulations of Theoretical Ecosystem Growth Model (TEGM) during various climate conditions. - Applied Ecology and Environmental Research 7(1): 71-78.

[8] Eppich, B., Dede, L., Ferenczy, A., Garamvölgyi, A., Horváth, L., Isépy, I., Priszter, Sz., Hufnagel, L. (2009): Climatic effects on the phenology of geophytes. - Applied Ecology and Environmental Research 7(3): 253-266.

[9] Ferenczy, A., Eppich, B., Varga, R.D., Bíró, I., Kovács, A., Petrányi, G., Hirka, A., Szabóki, CS., Isépy, I., Priszter, SZ., Türei, D., Gimesi, L., Garamvölgyi, Á., Homoródi, R., Hufnagel, L. (2010): Comparative analysis of the relationship between phenological phenomena and meteorological indicators based on insect and plant. - Applied Ecology and Environmental Research 8(4): 367-376.

[10] Gasc, J.P., Cabela, A., Crnobrnja-Isailovic, J., Dolmen, D., Grossenbacher, K., Haffner, P., Lescure, J., Martens, H., Martinez Rica, J.P., Maurin, H., Oliveira, M.E., Sofianidou, T.S., Veith, M., Zuiderwijk, A. (1997): Atlas of Amphibians and Reptiles. - Backhuys Publishers

[11] Gergócs, V., Hufnagel, L. (2009): Application of Oribatid Mites as indicators (Review). Applied Ecology and Environmental Research 7(1): 79-98.

[12] Gergócs, V., Garamvölgyi, Á., Hufnagel, L. (2010): Indication strength of coenological similarity patterns based on genus-level taxon lists. - Applied Ecology and Environmental Research 8(1): 63-76.

[13] Hagemeijer, W.J.M., Blair, M.J. (1997): Atlas of European Breeding Birds. - T. \& A. D. Poyser 
[14] Haylock, M.R., Hofstra, N., Klein Tank, A.M.G., Klok, E.J., Jones, P.D., New, M. (2008): A European daily high-resolution gridded dataset of surface temperature and precipitation. - J. Geophys. Res. (Atmospheres) 113: D20119

[15] Horváth, L. (2007): Földrajzi analógia meghatározásának néhány módszere és alkalmazási lehetôsége [Methods to determine geographical analogy and possible applications]. - Klíma-21 Füzetek 50: 54-57.

[16] Horváth, L. (2008a): Use of the spatial analogy method to analyze to possible land-use change in Hungary. - Klíma-21 Füzetek 55: 23-27.

[17] Horváth, L. (2008b): Földrajzi analógia alkalmazása klímaszcenáriók elemzésében és értékelésében. [Application of geographical analogy to climate change scenario analysis and assessment $]-\mathrm{PhD}$ Theses, Corvinus University of Budapest.

[18] Jackson, S.T., Overpeck, J.T. (2000): Responses of plant populations and communities to environmental changes of the late Quaternary. - In: Erwin, D.H., Wing, S.L. (eds.) Deep Time: Paleobiology's Perspective - Paleobiology 26 (Supplement No. 4): 194-220.

[19] Kocsis, M., Hufnagel, L. (2011): Impacts of climate change on Lepidoptera species and communities. - Applied Ecology and Environmental Research 9(1): 43-72.

[20] Ladányi, M., Hufnagel, L. (2006): The effect of climate change on the population of sycamore lace bug (Corythuca ciliata, SAY, Tingidae Heteroptera) based on a simulation model with phenological response. - Applied Ecology and Environmental Research 4(2): 85-112.

[21] McLaughlin, J.F., Hellmann, J.J., Boggs, C.L., Ehrlich P.R. (2002): Climate change hastens population extinctions. - P. Natl. Acad. Sci. USA, 99: 6070-6074.

[22] Mitchell-Jones, A.J., Amori, G., Bogdanowicz, W., Krystufek, B., Reijnders, P.J.H., Spitzenberger, F., Stubbe, M., Thissen, J.B.M., Vohlarik, V., Zima, J. (1999): The Atlas of European Mammals. - T. \& A. D. Poyser.

[23] Moritz, C., Patton, J.L., Conroy, C.J., Parra, J.L., White, G.C., Beissinger, S.R. (2008): Impact of a Century of Climate Change on Small Mammal Communities in Yosemite National Park, USA. - Science 322: 261-264.

[24] Nakicenovic, N., Swart, R., eds. (2000): Emissions Scenarios. A special reports of IPCC Working Group III. - Cambridge University Press, UK. 570p.

[25] Petrányi, G., Hufnagel, L., Horváth, L. (2007): A klímaváltozás és a biodiverzitás kapcsolata - földrajzi analógiai esettanulmány az európai lepkefaunára [Climate change and biodiversity - case study of a geographical analogy focusing on the European Lepidoptera fauna] - Klíma-21 Füzetek 50: 62-69.

[26] Pounds, J.A., Bustamante, M.R., Coloma, L.A., Consuegra, J.A., Fogden, M.P.L., Foster, P.N., La Marca, E., Masters, K.L., Merino-Viteri, A., Puschendorf, R., Ron, S.R., Sanchez-Azofeifa, G.A., Still, C.J., Young, B.E. (2006): Widespread amphibian extinctions from epidemic disease driven by global warming. - Nature 439: 161-167.

[27] Rosenzweig, C., Casassa, G., Karoly D.J., Imeson, A., Liu, C., Menzel, A., Rawlins, S., Root, T.L., Seguin, B., Tryjanowski, P. (2007): Assessment of observed changes and responses in natural and managed systems. - In: Parry, M.L., Canziani, O.F., Palutikof, J.P., van der Linden, P.J., Hanson, C.E. (eds.) Climate Change: Impacts, Adaptation and Vulnerability. Contribution of Working Group II to the Fourth Assessment Report of the Intergovernmental Panel on Climate Change, Cambridge University Press, Cambridge, UK.

[28] Rosenzweig, C., Karoly, D., Vicarelli, M., Neofotis, P., Wu, Q., Casassa, G., Menzel, A., Root, T.L., Estrella, N., Seguin, B., Tryjanowski, P., Liu, C., Rawlins, S., Imeson, A. (2008): Attributing physical and biological impacts to anthropogenic climate change. Nature 453: 353-357, doi:10.1038/nature06937.

[29] Sekercioglu, C.H., Daily, G.C., Ehrlich, P.R. (2004): Ecosystem consequences of bird declines. - P. Natl. Acad. Sci. USA, 101: 18042-18047. 
[30] Sipkay, Cs., Horváth, L., Nosek, J., Oertel, N., Vadadi-Fülöp, Cs., Farkas, E., DrégelyiKiss, Á., Hufnagel, L. (2008): Analysis of climate change scenarios based on modelling of the seasonal dynamics of a Danubian copepod species. - Applied Ecology and Environmental Research 6(4): 101-108

[31] Sipkay, Cs,.Kiss, K.T., Vadadi-Fülöp, Cs., Hufnagel, L. (2009): Trends in research on the possible effects of climate change concerning aquatic ecosystems with special emphasis on the modelling approach. - Applied Ecology and Environmental Research 7(2): 171198.

[32] Sutherst, R.W., Maywald, G.F. (1998): CLIMEX - A bio-geographical approach to entomology. - In: Zalucki, M.P., Drew, R.A.I., White, G.G. (eds) Pest Management Future Challenges, Proc. 6th Australasian Applied Entomological Research Conference, University of Queensland, Brisbane.

[33] Thomas, C.D., Cameron, A., Green, R.E., Bakkenes, M., Beaumont, L.J., Collingham, Y.C., Erasmus, B.F.N., Ferreira de Siquera, M., Grainger, A., Hannah, L., Hughes, L., Huntley, B., van Jaarsveld, A. S., Midgley, G.F., Miles, L., Ortega-Huerta, M.A., Townsend, A., Peterson, O., Phillips, L., Williams, S.E. (2004): Extinction risk from climate change. - Nature 427: 145-148

[34] Williams, S.E., Bolitho, E.E., Fox, S. (2003): Climate change in Australian tropical rainforests: An impending environmental catastrophe. - Proc. Biol. Sci. 270: 1887

[35] Williams, J.W., Jackson, S.T., Kutzbach, J.E. (2007): Projected distributions of novel and disapearing climates by 2100. - AD Proceedings of the National Academy of Sciences 104: 5738-5742.

[36] Young, A.M., Blackshaw, B., Maywald, G.F., Sutherst, R.W. (1999): CLIMEX for Windows 1.1. Tutorials. - CSIRO, Melbourne. 